\title{
Telomerase Expression Increased the Risk of Borderline Ovarian Tumors
}

\author{
Ekspresi Telomerase Meningkatkan Risiko Tumor Ovarium Borderline \\ Mila Maidarti' ${ }^{1}$ Andrijono1, Primaria Dewi ${ }^{2}$, Joedo Prihartono ${ }^{3}$ \\ ${ }^{1}$ Department of Obstetrics and Gynecology \\ ${ }^{2}$ Department of Pathology Anatomy \\ ${ }^{3}$ Department of Public Health \\ Faculty of Medicine University of Indonesia/ \\ Dr. Cipto Mangunkusumo Hospital \\ Jakarta
}

\begin{abstract}
Objective: To compare the expression of telomerase in benign ovarian tumors and borderline ovarian tumors.

Methods: Thirteen samples of paraffin blocks of ovarian borderline tumors and benign ovarian tumors were taken from patients who underwent surgery from January 2006 to December 2011. In all samples, we performed immunohistochemical staining to the paraffin blocks. Semi quantitative determination of the expression of telomerase is done by an Anatomic Pathology specialist and Gynecologist, which already had the same perception about assessing the standardization sample. We used Fisher's test to analyze the data.

Results: There were significant relationship in the moderate expression of telomerase in the nucleus and cytoplasm between benign and borderline ovarian tumors, with an odds ratio of moderate telomerase expression in the cytoplasm and nucleus of 19.3 (95\% CI: 1.4 - 943) and 26 (95\% CI : 2.3 - 1211). This means that the risk of borderline ovarian tumors in the expression of moderate telomerase in the cytoplasm was 3.19 times compared to the negative expression, whereas in the nucleus it became 26-fold. There is no significant relationship among menopause, age, and telomerase expression in the nucleus and cytoplasm.

Conclusion: There are significant differences in the expression of moderate strength telomerase in nucleus and cytoplasm between benign and borderline ovarian tumors.

[Indones J Obstet Gynecol 2013; 37-1: 32-40]

Keywords: benign ovarian tumor, borderline ovarian tumor, telomerase expression
\end{abstract}

\begin{abstract}
Abstrak
Tujuan: Membandingkan ekspresi telomerase pada tumor ovarium jinak dan tumor ovarium borderline.

Metode: Tiga belas sampel blok parafin tumor ovarium borderline dan tumor jinak ovarium diambil dari pasien yang menjalani operasi dari bulan Januari 2006 sampai bulan Desember 2011. Pada semua sampel parafin blok dilakukan pewarnaan imunohistokimia. Penentuan ekspresi telomerase secara semikuantitatif dikerjakan oleh dokter spesialis Patologi Anatomi dan dokter spesialis Obstetri Ginekologi, yang sebelumnya telah menyamakan persepsi mengenai penilaian standarisasi sampel. Analisis statistik menggunakan uji Fisher.

Hasil: Terdapat hubungan bermakna ekspresi telomerase sedang dan negatif di inti dan sitoplasma dengan tumor jinak ovarium dan tumor ovarium borderline, dengan odd ratio ekspresi telomerase sedang di sitoplasma dan inti sebesar 19,3 (IK 95\%: 1,4 - 943) dan 26 (IK 95\%: 2,3 - 1211). Ini berarti bahwa risiko terjadinya tumor ovarium borderline pada ekspresi telomerase sedang di sitoplasma adalah 3,19 kali dibandingkan ekspresi negatif, sedangkan di inti 26 kali lipat. Tidak terdapat hubungan bermakna menopause dan usia dengan ekspresi telomerase di inti dan sitoplasma.
\end{abstract}

Kesimpulan: Terdapat perbedaan bermakna ekspresi telomerase kekuatan sedang di inti dan sitoplasma tumor jinak dan tumor ovarium borderline.

[Maj Obstet Ginekol Indones 2013; 37-1: 32-40]

Kata kunci: ekspresi telomerase, tumor jinak ovarium, tumor ovarium borderline.

Correspondence: Mila Maidarti, Jln. Pendidikan Raya 3 blok I/128 Duren Sawit. Jakarta Timur, Telephone: 08119679592.

Email: milamaidarti@gmail.com

\section{INTRODUCTION}

One in 70 women will be suffering from ovarian cancer during her life, and borderline ovarian tumors present in 15\% of all epithelial ovarian tumors. Borderline ovarian tumors are neoplasms with changes in cell proliferation greater than that seen in benign ovarian tumors of the same type, but showed no destruction or invasion of the ovarium stroma. ${ }^{1}$ Histologic type of borderline ovarian tumors mostly found are serous or mucinous type that show the feature of epithelial proliferation, abnormal nucleus, and mitotic activity in the intermediate level, without any invasion into stroma. ${ }^{1,2}$

Compared with malignant epithelial ovarian tumors which are invasive, borderline ovarian tumors are found in young women and at an early stage, with a good prognosis. The incidence rate of borderline ovarian tumors was lower than invasive ovarian cancer. ${ }^{2}$ Borderline ovarian tumors are often called 'ovarian tumors of low malignant potential' because of the low histological differentia- 
tion degree and the good prognosis. ${ }^{3}$ Pathogenesis of borderline ovarian tumors remain unclear, the clinical management is still controversial, especially for borderline ovarian tumors serous type, which is a type of borderline ovarian tumors mostly found. ${ }^{4}$

Ovarian cancer pathophysiology has not been clear until now. One of the interesting things to examine is the role of telomerase in cell aging process. Telomerase is a complex ribonucleoprotein that adds base sequences at the 3 'end of DNA telomere. Telomere length is maintained by telomerase, which is a specific DNA polymerase. Telomere in humans will be shortened progressively along with cell division. ${ }^{5}$ Malignant cells have high telomerase activity so referred as the survival cells that will continue to survive. ${ }^{6,7}$ Telomerase activity has been widely found in various kinds of malignant ovarian tumors, and rarely found in benign tumors or normal ovarian tissue. ${ }^{8}$ Telomerase can be used as a prognostic indicator in several types of cancer, in which telomerase activity increased in line with tumor progression. . $^{9-11}$

Borderline ovarian tumors are tumors that are interesting to study because it is not benign nor malignant tumors. Telomerase activities in borderline ovarian tumors vary in several studies. Several studies had shown that telomerase activity ranged between $60-100 \%$, while other studies showed the number to be $17-20 \% .^{7}$ Telomerase is active in most tumor cells, but not in normal somatic cells, and can prevent progressive telomere shortening in the presence of cell division, causing tumor cells grew faster than normal cells. ${ }^{9,10}$ Stabilization of telomeres by telomerase can lead to unlimited cell proliferation. ${ }^{12}$ In malignant tumors such as leukemia, breast cancer, and meningioma, telomerase activity associated with a poor prognosis. Up until now there is no sufficient data to determine the role of telomerase as a factor in ovarian cancer prognosis. $^{7}$ So we need a study to determine the effect of highly telomerase activity in malignant ovarian in relation to carcinogenesis of ovarian cancer so that it can be used as the basis for subsequent studies as a prognostic approach and treatment of malignancy, especially in malignant epithelial ovarian tumors. The purpose of this study is to determine the expression of telomerase in benign ovarian tumors, borderline ovarian tumors and assess the comparative telomerase expression in borderline and benign ovarian tumors.

\section{METHOD}

This study was a case-control study. Research was conducted at the Department of Obstetrics and Gynecology and Department of Pathology Anatomy Faculty of Medicine/RSUPNCM, started in July until November 2011.

Research sample was all paraffin blocks at the Department of Pathology Anatomy Faculty of Medicine/RSUPNCM of benign ovarian tumors and borderline ovarian tumors patients treated in oncology ward of Department of Obstetrics and Gynecology Faculty of Medicine/RSUPNCM from January 2006 to December 2011 and meet the inclusion criteria were specimens collected from January 2006, from patients who did not suffer from malignancies in other organs, and had a complete medical records. The exclusion criteria were the paraffin blocks of non-epithelial ovarian tumors. The sampling will be done in simple random sampling, where all the paraffin blocks of ovarian tumors that meet the criteria will be numbered, and some of them will be selected with the help of random tables. Based on the sample calculation, we obtained 13 samples of benign ovarian tumors and 13 borderline ovarian tumors.

The paraffin blocks of borderline ovarian tumors and benign ovarian tumors were stained immunohistochemically. The intensity of staining was evaluated subjectively using a scale ranging from $0=$ no stain, 1 = weak staining, 2 = moderate staining, 3 = strong staining. ${ }^{36}$ In every staining, we included a negative control by using the same ovarian tissue and each one time staining process, we made as much as 13 sample for case-control group with a positive control of endometrial cancer.

Telomerase expression in cytoplasm and nucleus, were assessed by immunohistochemical staining, using Burstman score. Assessment categories: number of positive cells: $0 \%=0 ;<10 \%=$ $1 ; 10-50 \%=2 ; 51-80 \%=3$; and $>80 \%=4$. The intensity of color: Weak $=1+$; Moderate $=2+$; Strong $=3+$. Then multiplied and the result: negative $=$ score 0 ; weak $=$ score $1 ;$ moderate $=$ score 2-6; strong = score 8-12.

The research data were recorded on the form of research that had been tested. After going through the process of editing and coding, data that has been a net will be processed and compiled in distribution and cross-table tabular form according to the purpose of research, using SPSS software ver- 
sion 17.0. The relationship between telomerase expression in borderline ovarian tumors and benign ovarian tumors was assessed by chi square tests or Fisher. The predictive value is considered significant if $\mathrm{p}$ value $<0.05$. This research had received approval from the Faculty of Medicine Research Ethics Committee.

\section{RESULT}

Data were obtained from immunohistochemical examination of 26 paraffin block samples which were still in a good condition. Samples were derived from borderline ovarian tumors and benign ovarian tumor patients treated at the oncology ward of Department of Obstetrics and Gynecology Faculty of Medicine/RSUPNCM Jakarta in January 2006 to December 2011. Immunohistochemical examination of samples from both groups was done by assessing the number of positive cells and intensity in the nucleus and cytoplasm. Assessment of telomerase expression was carried out using Burstman scores, then the samples divided into groups of strong, moderate, weak and negative. The data obtained from the examination was then processed using SPSS version 17.0 for windows. The number of cases, of patients with borderline ovarian tumors were 13 people, and control group consisted of 13 people. Fifteen patients (57.7\%) aged over 30 years and 11 (42.3\%) aged less than 30 years. The average age of patients with borderline ovarian tumors was older, and statistically significant ( $41 \pm 15$ year) compared to benign ovarian tumor group ( $25 \pm 10$ year).

To determine differences in age and parity groups of benign ovarian tumors and borderline ovarian tumors, we used the Mann Whitney test because the data is abnormally distributed. To find out the difference proportion of women who had experienced menopause and have not experienced menopause, and the proportion of histologic types in each group, we used Chi square or Fisher test. There are significant differences in the number of patients who had experienced menopause in the group of benign ovarian tumors and borderline ovarian tumors. Histopathology types of benign ovarian tumors are mostly mucinous, but there were no significant differences in the proportion of serous and mucinous types in both groups.
Table 1. The baseline characteristic of patients

\begin{tabular}{lccc}
\hline \hline $\begin{array}{c}\text { Patients } \\
\text { characteristic }\end{array}$ & $\begin{array}{c}\text { Benign ovarian } \\
\text { tumors }\end{array}$ & $\begin{array}{c}\text { Borderline } \\
\text { ovarian tumors }\end{array}$ & $\begin{array}{c}\mathbf{p} \\
\text { value }\end{array}$ \\
\hline Age & $25 \pm 10$ & $41 \pm 15$ & $0.008^{*}$ \\
Parity & $1(0-3)$ & $2(0-8)$ & $0.047^{*}$ \\
Menopausal status & & & $0.048^{* *}$ \\
$\quad$ Non-menopause & $13(50 \%)$ & $9(34.6 \%)$ & \\
$\quad$ Menopause & $0(0 \%)$ & $4(15.4 \%)$ & \\
Histologic types & & & $0.08^{* *}$ \\
$\quad$ Serous & $1(3.8 \%)$ & $5(19.23 \%)$ & \\
$\quad$ Mucinous & $12(46 \%)$ & $8(30.8 \%)$ & \\
Stage & & & \\
IA & & $9(69.2 \%)$ & \\
IIIC & & $4(30.8 \%)$ & \\
\hline \hline
\end{tabular}

*Mann Whitney test

${ }^{* *}$ Fisher test

We classified the samples into 4 different groups, namely the negative cases (score 0), weak expression (score 1), moderate expression (score 2-6), and strong expression (8-12). To determine the relationship between borderline and benign ovarian tumors and the telomerase expression in nucleus and cytoplasm, we used Fisher's test. The results of Fisher's test can be seen in the following table.

Table 2. Bivariate analysis of weak and moderate telo merase expression in the cytoplasm for case and control groups

\begin{tabular}{lccccc}
\hline \hline \multirow{2}{*}{$\begin{array}{c}\text { Telomerase } \\
\text { expression }\end{array}$} & \multicolumn{2}{c}{ Group } & $\begin{array}{c}\text { OR } \\
\text { Oovarderline }\end{array}$ & Benign ovarian \\
ovarian tumors & $\begin{array}{c}\text { B. 95\%) } \\
\text { tumors }\end{array}$ & $\mathbf{p}^{*}$ \\
\hline Weak & 1 & 2 & $3.5(0.03-313)$ & 0.42 \\
Negative & 1 & 7 & Reff & \\
Moderate & 11 & 4 & $19.3(1.4-943)$ & 0.005 \\
\hline \hline
\end{tabular}

*The predictive value (p) obtained via two-way Fisher's test

There is a significant relationship between negative and moderate telomerase expression in the nucleus and cytoplasm of benign ovarian tumors and borderline ovarian tumors, with an odds ratio of moderate telomerase expression in the cytoplasm and nucleus as much as 19.3 (95\% CI: 1.4 943) and 26 (95\% CI: 2.3 - 1211). This means that the risk of borderline ovarian tumors in the moderate telomerase expression in the cytoplasm was 3.19 times compared to the negative expression, whereas in the nucleus 26 -fold. In contrast, there was no significant difference in weak and negative telomerase expression for benign ovarian tumors and borderline ovarian tumors in the nucleus and cytoplasm. 
Table 3. Bivariate analysis of weak and moderate telomerase expression in the nucleus for case and control groups

\begin{tabular}{|c|c|c|c|c|}
\hline \multirow{2}{*}{$\begin{array}{l}\text { Telomerase } \\
\text { expression }\end{array}$} & \multicolumn{2}{|c|}{ Group } & \multirow{2}{*}{$\begin{array}{c}\text { OR } \\
\text { (CI 95\%) }\end{array}$} & \multirow{2}{*}{$\mathbf{p}^{*}$} \\
\hline & $\begin{array}{c}\text { Borderline } \\
\text { ovarian tumors }\end{array}$ & $\begin{array}{l}\text { Benign ovarian } \\
\text { tumors }\end{array}$ & & \\
\hline Weak & 0 & 1 & $1.3(0.02-30)^{* *}$ & 1.0 \\
\hline Negative & 4 & 12 & Reff & \\
\hline Moderate & 9 & 0 & $26(2.3-1211)^{* *}$ & 0.00 \\
\hline
\end{tabular}

*The predictive value (p) obtained via two-way Fisher's test

**Odds ratio is obtained by adding 1 to each cell, because there is a cell whose value is 0

To determine the relationship between the age and telomerase expression in the nucleus or cytoplasm, we used the two-way Fisher's test. The age was classified into two groups, which were $=30$ years old and $<30$ years old. According to two-way Fisher's test, there is no significant relationship be-

\section{Benign ovarian tumor}

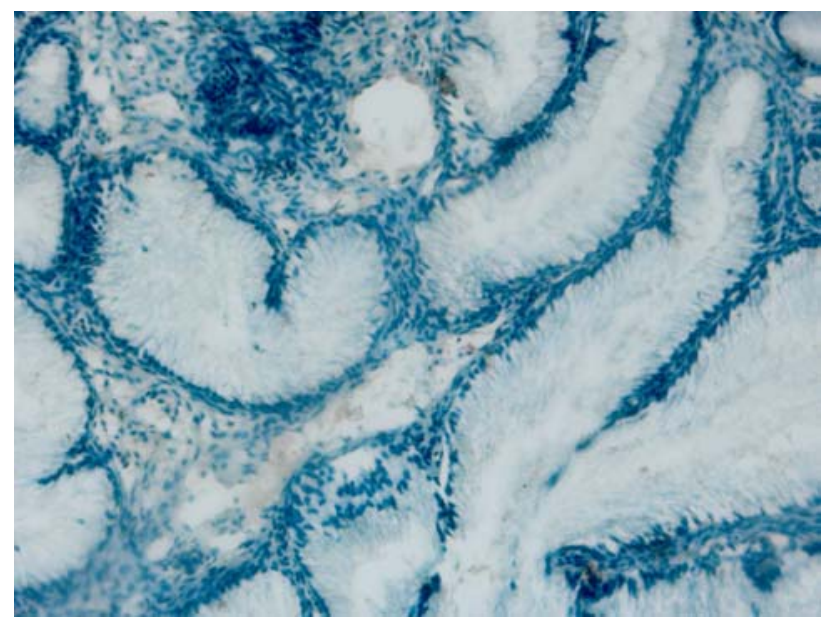

Positive control

\section{Borderline ovarian tumor}

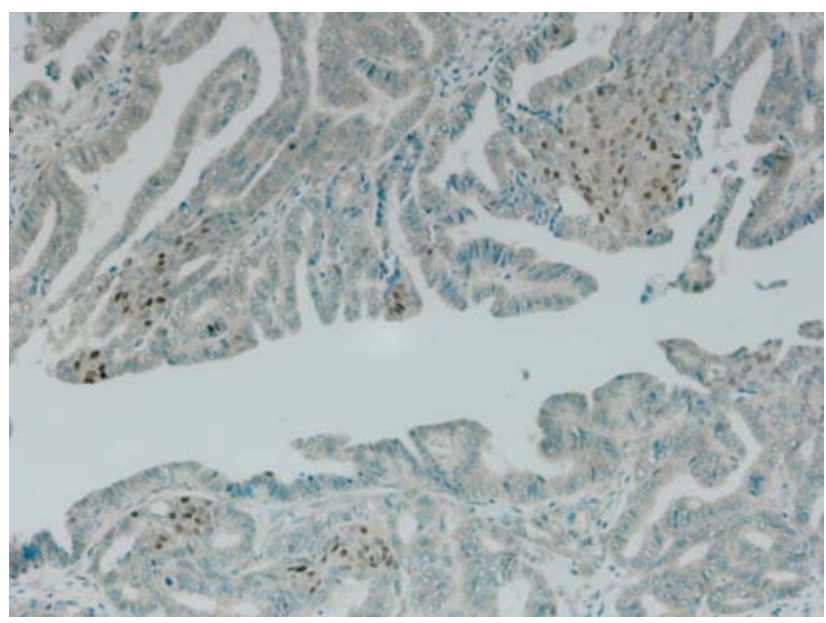

Negative control tween age and telomerase expression in the nucleus $(\mathrm{p}$ value $=0.1)$ nor the cytoplasm $(\mathrm{p}$ value $=$ 0.2). Based on two-way Fisher's test, we found no significant relationship between menopausal status and telomerase expression in the nucleus ( $p$ value $=0.11$ ) nor the cytoplasm ( $\mathrm{p}$ value $=0.3$ ). Telomerase expression in both the nucleus and cytoplasm in borderline ovarian tumors with serous and mucinous types showed no significant differences ( $p$ value $>0.05$ ). We analysed the relationship between borderline ovarian tumor stage and telomerase expression, and there is no significant relationship between borderline ovarian tumor stage and telomerase expression in the nucleus and cytoplasm ( $\mathrm{p}$ value $>0.05$ ).

These following pictures are immunohistochemical examinations of benign ovarian tumors and borderline ovarian tumors.

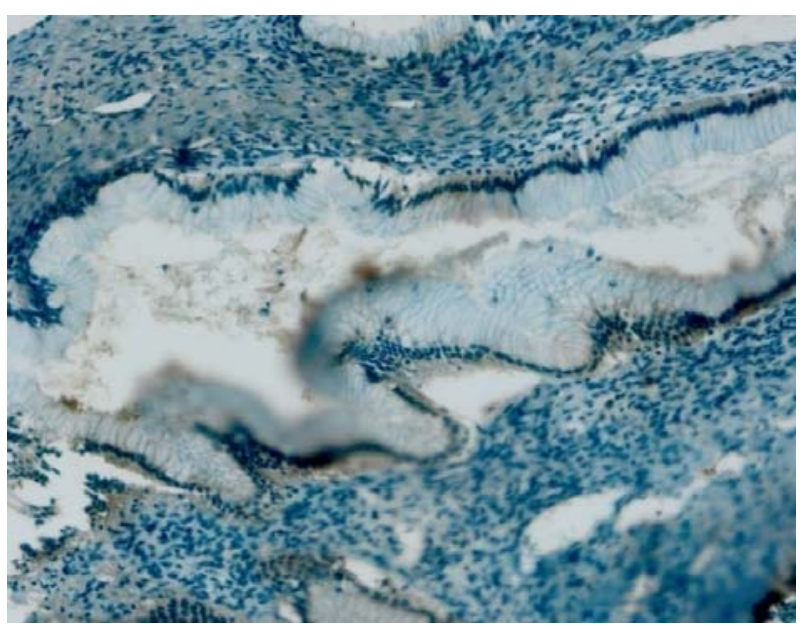

Weak cytoplasm expression

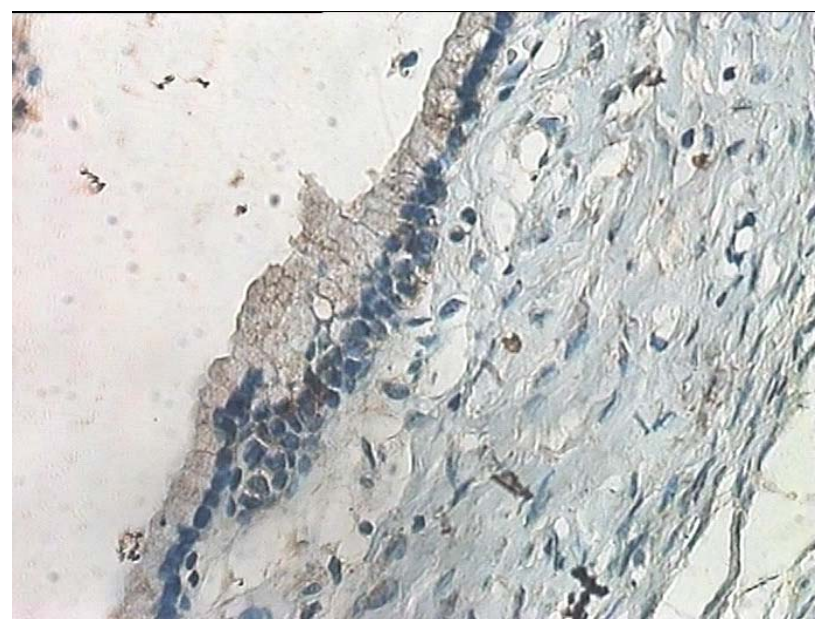

Weak cytoplasm expression 


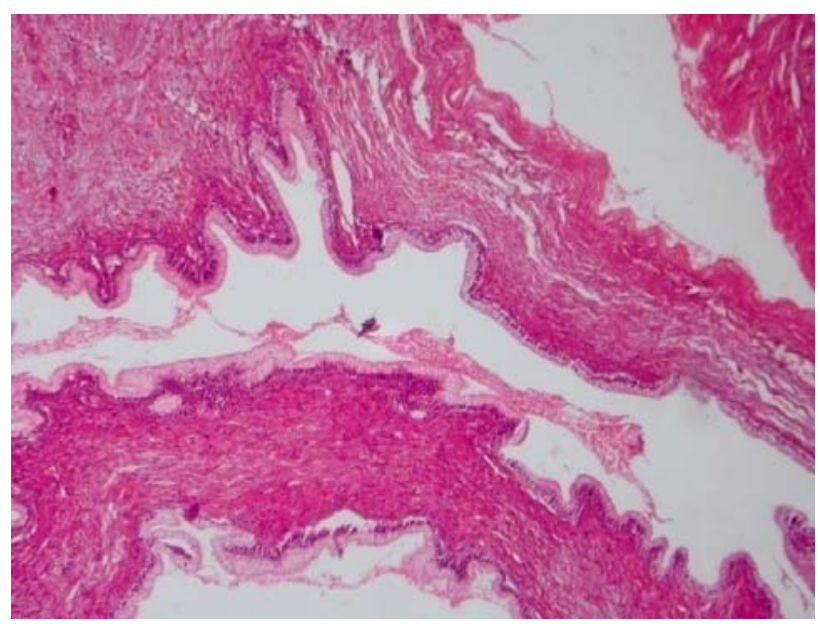

Haematoxilin eosin staining

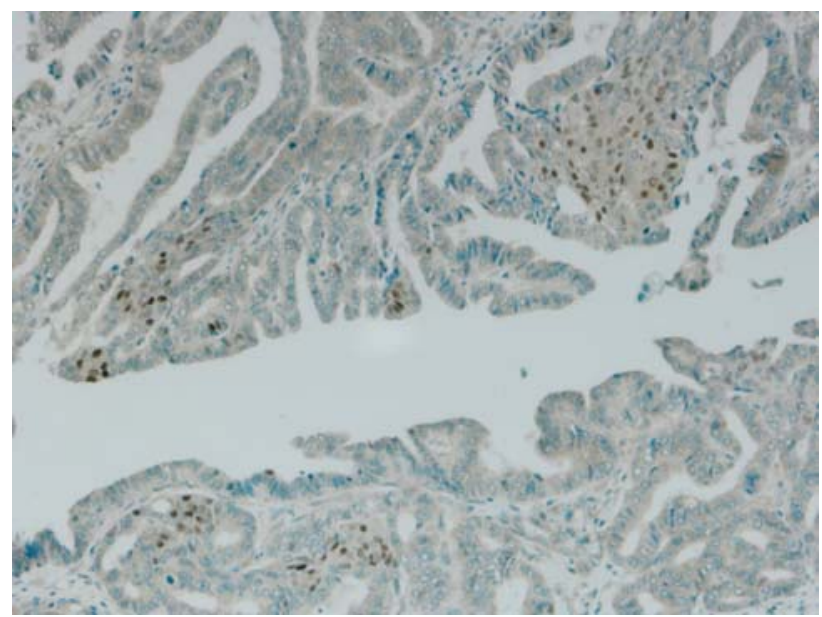

Positive control

\section{DISCUSSION}

Borderline ovarian tumors accounts for $10-15 \%$ of all epithelial ovarian tumors, more than $96 \%$ of its histopathology type is mucinosum or serous. Other types can be either endometrioid, clear cell or transitional cell tumors (Brenner). This study included 26 samples that are divided into two groups: case group, which is a sample derived from borderline ovarian tumors, a total of 13 samples, and the control group, which is originated from benign ovarian tumors, a total of 13 samples. In the case group, mean age of patients is higher $(41 \pm 15)$ than the control group $(25 \pm 10)$ and statistically significant. These results are consistent with research conducted by Ayhan et al, in which the average age of patients with borderline ovarian tumors was 41.77 $\pm 13.8844 .{ }^{13}$ The same conclusion is also reported by Berek, et al in 2007, who stated that borderline ovarian tumors mostly occur at age 30 - 50 years, while ovarian cancer generally occurs between the

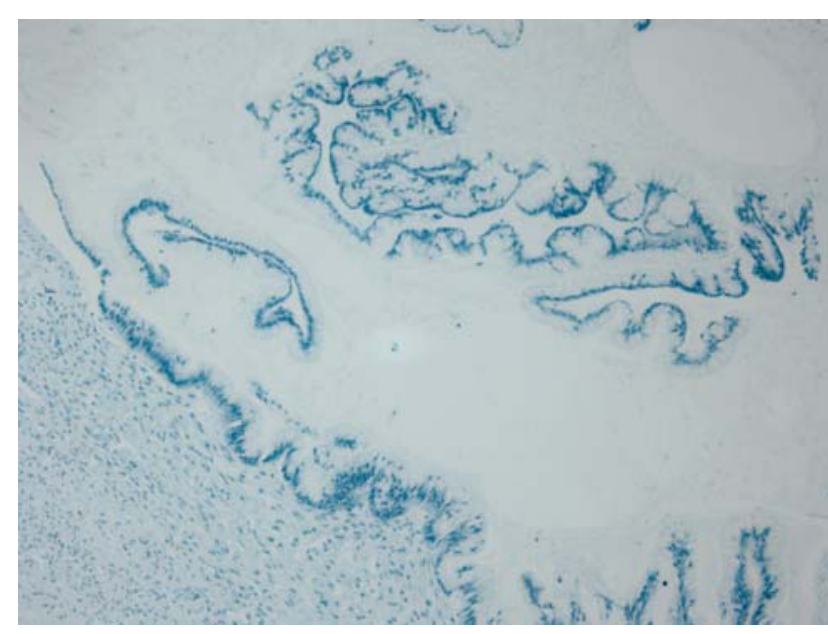

Negative control

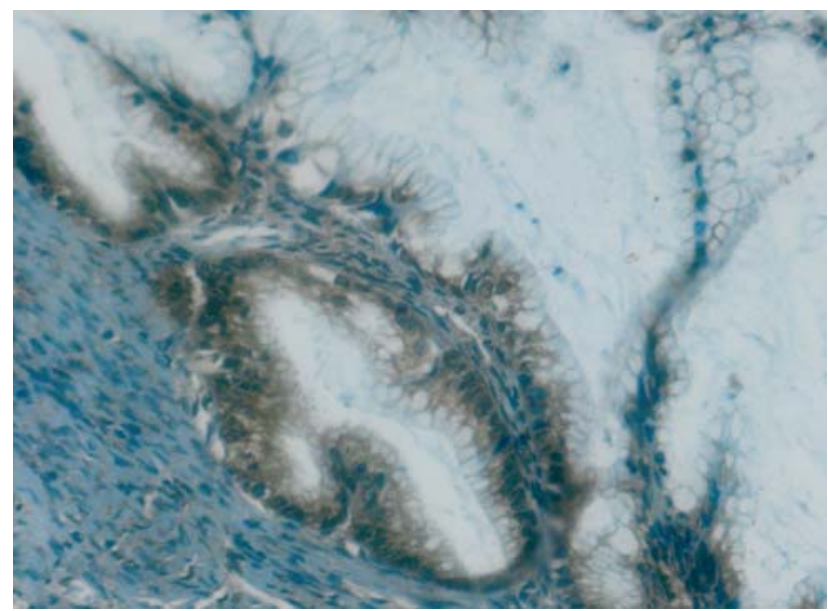

Weak telomerase nucleus/cytoplasm activity

ages of 50 - 70 years. Incidence of borderline ovarian tumors or invasive ovarian tumor is 1 in 10 patients aged 40 years, and after age 40 years, the incidence will increase to 1 in 3 women. ${ }^{10}$ It is because borderline ovarian tumor is neoplasm with changes in cell proliferation greater than that seen in benign ovarian tumors of the same type, but showed no destruction or invasion of the ovarium stromal. ${ }^{1}$ Levi, et al, 1999, stated that the borderline ovarian tumors are epithelial ovarian tumor whose invasion is limited, have a good prognosis and occurs at the younger age. ${ }^{14}$

In this study, multiparity patients are more widely available in groups of borderline ovarian tumors compared to benign ovarian tumors, and these differences were statistically significant $(\mathrm{p}=$ 0.047). This is contrasting to the research conducted by Riman et al, who reported that increasing parity reduces the risk of borderline ovarian tumor incidence. ${ }^{15}$ Parity is the most important 
nongenetic factor. Nagell and his colleagues analyzed the 12 case-control study in the United States and they reported a significantly decreased risk of ovarian cancer incidence in the presence of term pregnancies $(\mathrm{OR}=0.47)$. The risk of ovarian cancer decreased progressively with increasing number of pregnancy. ${ }^{16}$ Ovarian cancer is associated with low parity and infertility. The relationship between parity and infertility on the risk of developing ovarian cancer have led to the hypothesis that suppression of ovulation is probably an important factor. Theoretically, the epithelium surface having a decay and repair process repeatedly. This process is thought to cause a high probability of occurrence of mutations that can lead to oncogenic phenotype. ${ }^{10}$

The most commonly found histologic type of borderline ovarian tumors was serous, meanwhile the most commonly found histologic type of benign ovarian tumors was mucinous type. However, the difference was not statistically significant $(\mathrm{p}=$ 0.08). In some literature it is said that the most common histopathologic type of borderline ovarian tumors is serous. Research conducted by Ayhan A, 2005, reported that the most commonly found histopathologic type of borderline ovarian tumors was serous (54\%) followed by mucinous (39\%) and other types of $7 \% .^{13}$ Another study conducted by Levi, et al, stated the same thing, with the number of borderline ovarian tumors was 58\% serous, $41 \%$ mucinosum, and $1 \%$ of other types. ${ }^{14}$ Most borderline ovarian tumors found is on stage IA which accounts for $61.5 \%$. In accordance with research conducted by Andrijono, most borderline ovarian tumors were diagnosed at stage I (50\% $90 \%$ ), so the conservative surgery can be easily performed. ${ }^{17}$

All patients diagnosed as having benign ovarian tumors in this study have not been through menopause, while in the group of borderline ovarian tumors, there were four $(15.4 \%)$ patients who had experienced menopause. This is related to age of onset of borderline ovarian tumors, which generally occurs in older age compared to benign ovarian tumors. In this study the average age of patients in the benign ovarian tumors were younger, and statistically significant.

Measurement of telomerase activity varies widely, as a diagnostic and prognostic modalities for some cancers. In this study, we evaluated the expression of telomerase in 26 patients with be- nign ovarian tumors and borderline ovarian tumors. Expression of telomerase is not only found in the nucleus, but also in the cytoplasm. hTERT is the catalytic subunit of telomerase which is overexpressed in most tumor cells, and is required to maintain telomere length. Therefore, hTERT usually work in the nucleus cell. But hTERT is also found in the mitochondria, to maintain catalytic activity. Some studies suggest that hTERT translocation to mitochondria is in oxidative stress conditions. Phosphorylation at Tyr-707 in the presence of oxidative stress, causing translocation of hTERT from the nucleus to the cytoplasm and reduced antiapoptosis activity. Phosphorylation by AKT pathway led to hTERT location which is in the core. Transfer of hTERT from the nucleus to the cytoplasm is highly dependent on the cell cycle, phosphorylation status, transformation and DNA destruction. ${ }^{18}$

The only benign ovarian tumors that showed weak expression in the nucleus is the mucinosum type. There are five patients with mucinosum benign tumors that showed moderate expression in the cytoplasm. In the serous type benign tumor, telomerase expression was not found either in the nucleus nor the cytoplasm. However, the distribution of histopathology in benign tumors is uneven, where there is only one serous ovarian tumor. Burstman, 2005 conducted a study to determine the use of immunohistochemical expression of telomerase in benign tumors, borderline and malignant ovarian tumors. In this study, he reported that there is no telomerase expression in both the nucleus nor cytoplasm in benign ovarian tumors. Whereas in borderline ovarian tumors, 7 of 10 cases $(70 \%)$ showed strong expression of hTERT in the nucleus. ${ }^{9}$ Another study conducted by Kyo et al 1998, stated that telomerase activity most commonly found in malignant ovarian tumors, and very rarely found in benign tumors ovarium. ${ }^{19}$ Telomerase activity is positive in some benign ovarian tumors. Some of the regenerated tissue and proliferated cells showed that telomerase activity is lower. ${ }^{18}$

Most telomerase expression is obtained in groups of borderline ovarian tumors, both in the nucleus and the cytoplasm. In borderline ovarian tumors there were 4 samples that showed no telomerase activity in the nucleus, and one sample in the cytoplasm. Research conducted by Park et al, showed one borderline ovarian tumor samples and one sample of malignant ovarian tumors which 
showed no telomerase activity or hTERT gene expression. This likely occurs because the tumor has not yet demonstrated the telomerase regulation activity. However, the interesting thing is the existence of alternative mechanisms of telomere elongation in immortal cells and some tumors, even though there is no telomerase activity. ${ }^{20}$ We analyzed the data with chi-square with a $2 \times 2$ table and obtained statistically significant differences between the moderate telomerase expression in the cytoplasm. Research conducted by Kyo et al, Burtsman et al, on immunohistochemical examination to determine the expression of hTERT in ovarian tumors, reported that hTERT expression is not only happened in the nucleus, but also in the cytoplasm. This statement is supported by Western blot examination of the nucleus and cytoplasm extracts, where the nucleus and the cytoplasm showed a significant expression of hTERT. Biological function of hTERT cytoplasm remains speculative, the possibility of hTERT is located in the cytoplasm is prior to translocation to the nucleus. It is said that cytoplasmic hTERT is not phosphorylated and inactive and that the phosphorylation of hTERT associated with translocation from the cytoplasm to the nucleus. ${ }^{21}$

Chi-square analysis was used to determine the relationship between histologic type of tumor and telomerase expression in the nucleus, and significant results obtained on the relationship between the moderate expression in the nucleus $(\mathrm{p}=0.000)$. However, greater odds ratio is obtained for expression in the nucleus (26) compared to expression in the cytoplasm (19.3). Another study conducted by Sun, et al, to evaluate telomerase activity and hTERT expression in clinical pathology of ovarian tumors concluded that from 10 borderline ovarian tumors cases, telomerase activity assay is performed by RT-PCR analysis of hTERT mRNA and 2 of $10(20.0 \%)$ who showed telomerase activity. Telomerase activity in borderline ovarian tumors increased significantly compared to benign ovarian tumors and ovarian normal. ${ }^{22}$

Telomerase is believed to be critical for the continued growth of cancer cells, in the absence of this enzyme, telomere length in cells that are dividing will be too short for the next chromosome replication. This idea is supported by the presence of telomerase activity during progression of cancer cells that led to the interesting idea that the interference function of telomerase can be an efficient approach to cancer therapy. The truth that telom- erase is expressed in most, though not all, ovarian cancer, has potential applications for the detection of these tumors in clinical specimens. Malignant ovarian tumors usually spread to pelvic and abdominal cavity, unlike most other malignant tumors that rarely metastasize outside the cavity. Cytological examination of ascites fluid or pelvic or abdominal cavity fluid can be used to determine the activity of telomerase as a marker of tumorspecific, to complete the conventional approach for monitoring disease progression and theraupetic effects. $^{23}$

In this study, we found no significant relationship between age and the degree of telomerase expression in the nucleus and cytoplasm. Similar results were reported by Kyo, 1999 with a different inspection techniques ie no significant relationship between hTERT expression and age also clinical stage. ${ }^{24}$ Research conducted by Murakami, et al, 1997, which analyzes the length of telomeres in normal ovaries of women with varying ages to determine whether telomere shortening occurs in line with increasing age. It was found that, TRFs size range between 8-13 kbp and the length does not vary with increasing age. ${ }^{25}$ This is because there are other factors that affect the expression of telomerase. In a study conducted by Widschwendter et al, 2004 they found that hTERT methylation found more frequently in older patients. hTERT methylation never been found in ovarian cancer or in normal ovary patients aged less than 40 or 60 years. In that study, they also reported an increased frequency of experiencing hTERT methylation along with increasing age, while the expression of hTERT mRNA is not affected by age. ${ }^{26}$

We also analyze the relationship between menopause and telomerase expression, and found no statistically significant association between menopausal status with telomerase expression in the nucleus nor the cytoplasm. In contrast to research Burstman, 2005, that found increased expression of telomerase in the group of women who had experienced menopause compared to women who have not experienced menopause. ${ }^{9}$ Murakami, 1997 conducted a study of normal ovarian premenopausal women, and get a weak telomerase expression in the cortex 3 of $4(75 \%)$ premenopausal women (detected only $6 \mu \mathrm{g}$ protein extracts), but those expression is not found in the medulla. Telomerase activity was not found in normal ovaries of women who already menopause. ${ }^{25}$ Widschwendter et al, 2004, reported that telomerase 
is expressed by a very weak strength in normal ovaries. hTERT expression of ovarian cancer and normal ovarian significantly different. However, no statistically significant relationship found between age and telomerase expression. ${ }^{26}$

Statistical test is performed to determine the relationship between tumor stage and telomerase expression only for borderline ovarian tumors. Based on Fisher's statistical test, there was no statistically significant relationship between tumor stage and telomerase expression. This is consistent with research conducted Burstman, 2005, which reported no significant relationship exists between the stage and telomerase expression. In Burstman studies, they also used immunohistochemical staining, but the samples derived from borderline ovarian tumors and malignant ovarian tumors. Research conducted by Sun, et al reported an average increase of telomerase activity happened in advanced ovarian carcinoma (FIGO stage III / IV) than early-stage (FIGO stage I / II), but the level of telomerase activity between the two sub-groups did not differ significantly. ${ }^{13}$ The same is expressed by Widschwendter et al, 2004, who found no significant relationship between tumor stage, histopathology, and telomerase expression degree. ${ }^{26}$ Different results were reported by Satoru Kyo, et al who conducted a study to determine the relationship of telomerase activity and clinical pathology of ovarian tumors . Average telomerase activity in tumor stage Ia+, Ib, Ic, II, III, and stage IV was $30 \pm 10$, $38 \pm 9,47 \pm 23,54 \pm 17$ and $11 \pm 12$ units. Telomerase activity in stage IV was significantly higher than the stage of Ia+, Ib, Ic, and stage II. This suggests that telomerase activity increases with ovarian cancer progression. ${ }^{20}$

Although some literature said that hTERT expression is regulated differently in various tissues, it is strongly influenced by several control mechanisms, such as a tumor suppressor, inhibition of the cell cycle, hormone receptors and protein virus. ${ }^{20}$ All serous papilyferum types of borderline ovarian tumors express telomerase with moderate strength in the nucleus and cytoplasm, however there is no statistically significant relationship between the histologic types of ovarian borderline tumors with telomerase expression. Research conducted by Tantbirojn et al, reported that the serous type of borderline ovarian tumors highest level of hTERT expression. Overall there were no significant differences between immunoreactivity of borderline ovarian tumors and their histology type. hTERT immunoreactivity in that study were not found in benign tumors ovarium. ${ }^{27}$ Sehdev et al, 2003 reported that serosum papiliferum type of borderline ovarian tumor tend to bilateral (59-82\%), ovarian surface involvement (50-65\%), found in an advanced stage (43-84\%), microinvasive focus and invasive implants (16-91\%), so that the recurrence incidence is high. ${ }^{28}$

This study has several drawbacks, including the limited number of cases. Despite the limitations, this study can be counted as a preliminary study, and it is necessary to conduct further studies with more samples.

\section{CONCLUSION}

Benign ovarian tumors mostly express telomerase with the moderate strength in the cytoplasm. Borderline ovarian tumors express telomerase with the moderate strength in the nucleus. There is a significant relationship between borderline ovarian tumors and benign ovarian tumors with moderate and negative telomerase expression in the nucleus and the cytoplasm.

Further research with larger sample size is needed to determine the role of telomerase expression as a diagnostic and prognostic modalities for ovarian tumors and comparison of quantitative and semiquantitative examination to assess the expression of telomerase in each type of ovarian tumors.

\section{REFERENCES}

1. Riman T, Dickman PW, Nilsson S, Correia N, Nordlinder H, Magnusson CM, Persson IR. Risk Factors for Epithelial Borderline Ovarian Tumors: Results of a Swedish Case-Control Study. J Gynecol Oncol. 2001; 83: 575-85.

2. Bulleti C, Albonetti A, Talamo T, Reggiani LB, Giacomucci E, Alfieri S, Flamigni C. Treatment Strategies of The Borderline Ovarian Tumors. 2. 1996: 24 - 8.

3. Boy Busmar. Kanker Ovarium: Farid Aziz, Andrijono, Saifuddin $\mathrm{AB}$, editor. Buku Acuan Nasional Onkologi Ginekologi. Edisi I. Jakarta, 2006; 468-512.

4. Shih LM, Kurman RJ. Molecular Pathogenesis of Ovarian Borderline Tumors: New Insights and Old Challenges. Clin Cancer Res 2005; 11.

5. Avilion AA, Piatyszek MA, Gupta J, Shay JW, Bacchetti S, Greider CW. Human Telomerase RNA and Telomerase Activity in Immortal Cell Lines and Tumor Tissues. Cancer research 56. 1996: 645-50.

6. Liu J, Yang G, Lanza T, Glassman A, Hayes K, Patterson A, Marquez RT, Auersperg N, Yu Y, Hahn WC, Mills GB, Bast RC. A Genetically Defined Model for Human Ovarian Cancer. Cancer Research 2004; 64: 1655-63. 
7. Wisman GB, Helder MN, De jong S, De vries GE, Van der zee GJ. Telomerase In Ovarian Cancer: A Possible Diagnostic Tool And Therapeutic Target? In: Jacobs IJ, Shepard JH, Oram DH, Blackett AD, Luesley DM, Berchuck A, Hudson CN. Ovarian Cancer. Oxford University Press, 2001: 275-8.

8. Cvetkovic D. Early Events in Ovarian Oncogenesis: A review. Reprod Biol Endocrinol; 2003: 1-7.

9. Brustmann H. Immunohistochemical Detection of Human Telomerase Reverse Transcriptase (hTERT) and c-kit in Serous Ovarian Carcinoma: A Clinicopathologic Study. Gynecol Oncol. 2005; 98: 396-402.

10. Berek JS. Epithelial Ovarian Cancer. In: Berek JS, Hacker NF. Practical Gynecologic Oncology, $4^{\text {th }}$ Ed. Philadelphia: Lippincott Williams \& Wilkins; 2005: 443-509.

11. Terasawa K, Sagae S, Takeda T, Ishioka S, Kobayashi K, Kudo R. Telomerase Activity In Malignant Ovarian Tumors with Deregulation of Cell Cycle Regulatory Proteins. Cancer Letters. 1999; 142: 207-17.

12. Akheshima R, Kigawa J, Oishi T. Telomerase Activity and p53-dependent apoptosis in Ovarian Cancer Cells. Bri J Cancer. 2001; 11:1551-5.

13. Ayhan A, Guven ES, Guven S. Recurrence and prognostic factors in borderline ovarian tumors. Gynecol Oncol. 2005; 98: 439-45.

14. Levi F, Vecchia CL. Borderline ovarian tumours in Vaud, Switzerland: incidence, survival and second neoplasms. Bri J Cancer. 1999; 79: 4-6.

15. Riman T, Dickman PW, Nilsson S, Correia N, Nordlinder H, Magnusson CM, et al. Risk factors for epithelial borderline ovarian tumors: results of a Swedish case-control study. Gynecol Oncol 2001; 83: 575-85.

16. Nagell V, R John. Ovarian Cancer: Etiology, Screening and Surgery. In: Rock JA, Jones HW. Te Linde's Operative Gynecology $9^{\text {th }}$ ed. Philadelphia: Lippincott Williams \& Wilkins 2003: 1487-95.

17. Andrijono. Sinopsis Kanker Ginekologi. Jakarta. 2004: 93102.

18. Galluzzi L, Morselli E, Kepp O, Vitale I. Mitochondrial gateways to cancer. Molecular Aspects Med. 2010; 31: 1-20.
19. Kyo S, Takakura MT, Murakami K, Saitoh R, Hirano H, Inoue M. Quantitative Differences in Telomerase Activity among Malignant, Premalignant, and Benign Ovarian Lesions. Clini Cancer Research. 1998; 4: 399-405.

20. Park TW, Riethdorf S, Riethdorf L. Differential telomerase activity, expression of the telomerase catalytic sub-unit and telomerase-rna in ovarian tumors. Int J Cancer 1999; (84): 426-31.

21. Kyo S, Masutomi K, Maida Y, Kanaya T, Yatabe N, Nakamura $M$, et al. Significance of immunological detection of human telomerase reverse transcriptase. Am J Pathol 2003; 163: 859-67.

22. Sun L, Wei M, Luo G, Liu J, Wang A, Mustea D, Könsgen W, Lichtenegger J, Sehouli. The telomerase activity and expression of hTERT gene can serve as indicators in the anti-cancer treatment of human ovarian cancer. Euro J Obstet Gynecol Reprod Biol. 2003; 130: 249-57.

23. Wan M, Zhi Li W. Telomerase Activity in Benign and Malignant Epithelial Ovarian Tumors. J the National Cancer Institute. 1997; 89: 437-41.

24. Kyo S, Kanaya T, Takakura M, Tanaka M, Yamashita A. Expression of human telomerase subunits in ovarian malignant, borderline and benign tumors. Int J Cancer. 1999; (80): 804-9.

25. Murakami J, Nagai N, Ohama K. Telomerase Activity in Ovarian Tumor. Am Cancer Society. 1997; 80: 1085-92.

26. Widschwendter A, Muller HM, Hubalek MM, Wiedemair A, Goebel HF, Holzner EM. Methylation status and expression of human telomerase reverse transcriptase in ovarian and cervical cancer. Gynecol Oncol. 2004; 93: 407-16.

27. Tantbirojn $P$, Triratanachat $S$, Trivijitsilp $P$, Niruthisard $S$. Human Telomerase Reverse Transcriptase (hTERT) Expression in Borderline Ovarian Tumors: An Immunohistochemical Study. J Med Assoc Thai. 2009; 92(3): 308-14.

28. Smith Sehdev AE, Sehdev PS, Kurman RJ. Noninvasive and invasive micropapillary (low-grade) serous carcinoma of the ovary: a clinicopathologic analysis of 135 cases. Am J Surg Pathol 2003; 27: 725-36. 